\title{
ALEXANDER'S TALE OR A COLLECTION OF SYMBOLS ACCORDING TO THE KUSH-NAMEH
}

\author{
Daryoosh AKbarzadeh \\ Research Institute of ICHTO, Iran
}

\section{Introduction:}

R elations between Iran and China most probably go back to This historical relation was practically in two ways: A) The Great Khorasan Road (Silk Road); and B) The Persian Gulf (Akbarzadeh: 2007, 1). The name An-shi is a well-known name in eastern texts which is translated as "Parthian," who were on the other end of the Silk Road, the gateway where different cultures met with each other.

The Sogdians who were famous traders of the Silk Road played an important role between eastern and western Asia (Vaissiere: 2005, 97). They brought Iranian cultural heritage to China and its surrounding regions.

In the Sasanian period (224 - 651 AD) is another important period for cultural relations between Iran and China. Various Sasanian cultural artifacts, such musical instruments, glassware, inscriptions and painting are found in China (An: 2010, 1).The influence of Sasanian heritage is confirmed by scholarly work and research in Japan (Nara) and Silla (Korea) (Akbarzadeh: 2013, 226).

Medieval Muslim scholars have also provided important information on the Silk Road, the trade networks and religious relations between Iran and China (Daryaee: 2010, 404). There are different and unique data to be found in the reports of these Medieval Persian authors which are less studied or noticed. It is important to note that some of these reports are comparable with pre-Islamic texts. 


\section{Kush-nameh:}

The Kush-nameh (1998) is one of the most important epics of classical Persian literature. This text dates to the early $5^{\text {th }}$ century Hejira (11 AD) and follows the style of the Shah-nameh (Book of King) (Akbarzadeh: 2013, 226). The author of the text, Iran-shan ibn Abal Khayr, relates in his epic that a community of Iranians had lived in China for generations since Jamshid's time. In fact the famous mythical king, Jamshid and his escape to the Eastern Clime is a famous tale in Middle Persian and Islamic texts. Iran-Shan explains how Iranians confronted various problems in China and why there were conflicts between Iranians and the Chinese kingdoms, and that as a result the Iranians decided to ask the ruler of Māchin for help. The ruler of Māchīn advised them to escape to Basilla and the Iranians finally immigrated to there (Akbarzadeh: 2010, 141).

In the introduction to the Kush-nameh, Iran-shan ibn Abal Khayr explains that with the help of a friend, he carefully used an "original source" for his work (127-134):

"I had a noble friend in my city who was a knowledgeable and important person. He told me: I give you a written text related to China, if you plan to write a new book..."

\section{KN and Alexander's Tale:}

Iran-shan explains the different tales related to Greek (-Roman) kings in the first part of the Kush-nameh which is unique amongst Persian epic texts. This part strongly suggests that the tales of GreeceRome (Byzantine: i.e. No. 545) were a fixed part of Parthian-Sasanian literature, both oral and written. It seems that the poet has used an original text to versify his work in this first part which cannot be related to the second part; he then created a link between the two parts and he focuses on Basilla in the second part. This kind of connection did not exist. The Kush-nameh can be seen as a heritage of collections of tales which had been made generations before poet. 
It seems that travelers of the Silk Road, Manicheans, Buddhists, Parthians, Kushans, Greek-Romans, all played a role and contributed to Iranian tales and made a new series of Iranian and non-Iranian tales, especially in the first part of the Kush-nameh (Akbarzadeh: $2013,27)$. In this rare case we are able to find symbols of such Iranian and non-Iranian cultures in the tales. The poet mentions in the passage about "Alexander's visit to the East", visiting the Kush's statue and the ruler of China:

554. Sar-e dastan-hay Shahan pish

555. hameh danesh o ray farhang o sang

556. ze khandan biaf-zayadat ray o hush

557. nebeshteh be Yunani o Pahlavi

558. ke chun bar Skandar jahan gasht rast

560. suy Khavar amad jahan-juy shah ke Khosrow hami dashti pish khish hameh chareh o pand o nirang o rang ze didan shegft ayadat ruy o gush chenin yaftam gar ze man beshnavi yeki gird giti hami gahst khast sipahi ke bar bad bast rah...

One the tales related to last kings, which nobles have in their possession, is a tale full of knowledge, arrangement, culture and wisdom, full of means, advice, charm and diversity. It was written in Greek and Pahlavi languages, the way I discovered them, believe (listen) me: When Alexander conquered the world, he decided to visit parts of the world. He went to East as a conqueror king, with a brave troop...

Firdowsi mentions a "Pahlavi narrator" at the beginning of Alexander's visit to (maybe through central Asia) India (Vol. VII), where there are similarities between this tale and same story in the $\mathrm{KN}$ :

103. chenin goft Guyandeh Pahlavi

shegiftat ayadat kin sokhan beshnavi

Thus the Pahlavi narrator says, you will admire it when you hear/ read it

The only difference between Firdowsi and Iran-shan is that the Kush-nameh mentions a "written text" (No. 557), but there is an "oral tradition" in the Shah-nameh. The fact that "bilingual Pahlavi-Greek" texts are mentioned in the Kush-nameh, reminds us of some Sasanian 
bilingual texts, as well as inscriptions (i.e. ŠKZ, ŠNRj). We know that during the reign of Shapur I texts on medicine, astronomy, logic, and texts on crafts and skills, which existed in India and Rome and other countries, were gathered and copies of these were made. "The community of Christians at Gundi-shahpuhr can be seen as another reason why the knowledge of Greek was familiar to Iranians. It was in this place that Greek medical books were translated into Syriac in the sixth century. The Sasanian profited from Greek and Indian sciences in Iran. The time of Khosrow I was the second major period where foreign teachings were influential" (Daryaee: 2009, 119). Another important period for foreign teachings is the reign of Khosrow II when The king accepted philosophers from Athens.

(Ibd. 120) writes: "One can state that Persia was a conduit for the transmission of knowledge between the Hellenic and Indic world in late antiquity."

Soon, foreign tales, as for example the arrival of Alexander, were preserved by Iranians - with some changes added- and by people who were interested in Greek- Roman and Byzantines cultures. Some of these tales, like Alexander's arrival, reached different parts of Iran, different tribes and communities of Iran, from north to south, and also infiltrated Iranian literature.

One of the stories of the Kush-nameh is related to both a SinoIranian cult as well as historical relations with the Greco-Roman world. Here, Persian literature renews relations between Iran, China and the Greek and Roman Empires. I think that the descriptions in the KN provide a unique report about how Buddhism, Manichaeism and Zoroastrianism and Islamic elements were mingled with the tale of Alexander's visit. All this was possible through the Silk Road and how historical relations were formed along this ancient road.

According to this tale Alexander visited the inscribed statue of Kush, the hero of the Kush-nameh. He continues to advance towards the East and finally visits people who are called "horse-face people" 
by poet, as their language is like the "voice of birds". They live in a mountainous place and Alexander decides to discover the "secrets of their life", especially manner of their "meals":

606. be porsid az ishan ze kar khoresh

ke chun ast o az chist in parvaresh 607. chenin dad pasokh kasi zan miyan ke ma ra khoresh hast az in mahiyan 608. ze tokhm gia o ze miveh khorim cho yabim az in har se bar nagzarim

Alexander asked them about their type of meal /nourishments, how they eat and what kinds of meals they had?

One of them answered our meals are of fish, and seeds (grains) and fruit; if we can find them, then we won't turn down any of these three.

They show Alexander the home of a wise man who is a kind of a leader (monk?) to them, and who lives in a cave in the mountains:

609. bedu goft kandar miyan gruh

611. vo piri hushmand ba farahi

614. hoshumand piri Mahan/e/sh be nam

615. yeki khaneh kardeh ast bar tigh kuh yeki mard yabim danesh-pezhu ke darad ze shahan pish agahi homana biyabad az ow shah kam gozideh jodaee o dur az gruh

One of them told Alexander we have a knowledgeable leader; he is clever old and he is a glorious man, he knows well the tales of previous kings. This knowledgeable old man is called Mahan/e/sh, and you will enjoy him (if you meet him). His home is located above the mountain; he lives in solitude, away from all.

Alexander meets Mahan/e/sh, an old man:

631. Skandar bedu goft benshin ze pay

633. ze nam o neshanat mara agahi ast

636. bedu goft kay pir pakizeh tan

640. si sad sal pish az to ay namdar

641. be khaneh dar amad jahandideh mard

644. sarasar nebeshteh bedu andarun ke ma ra be didar to hast ray neshastan be pish to az ablahist che dani nezhad man o nam man? bebin chehreh khish kardeh negar yeki pust ahu bar-avard zard gozashteh bedu sal sisad fozun

Alexander tells him: "please seat"! I want to see you carefully. (Old man told): I know you by your name and majesty, to seat in front 
of you is not respectful to you. (Alexander) told him that: Oh! Old man, beautiful body! how do you know my genealogy and my name? (Old man:) Oh, brave man, 300 years ago, I predicted my future (and events) ${ }^{1}$. The old man went to his home, he returned with a Parchment. This parchment was full of writing, it (parchment) was more than 300 years old.

Alexander asks him his genealogy, background and the kind of meals he has:

652. bedu goft kay shah mehman pir 653. chenin dad pasokh ke to pishtar 654. bedu farzaneh kay bi-hamal 655. ke man ruzeh nagshadeam joz be shab 656. magar an ke ruzi be sal andarun 657. dar an ruz yabad tanam parvaresh 658. kodam ast, goft, an gran-mayeh ruz 659. sevom ruz, gofta, ze Ordi-behesht 660. dar in ruz Adam be shod zin saray bebaydat khordan hami na-gozir az in miveh-ye pokhteh lakhti be khor bar amad homana 160 sal haman basteh daram ze goftar lab mara jashn kard Izad rahnamun vaz in miveh yabad ravanam khoresh ke bashad to ra zin neshan del-foruz? ke Yazdan ze bakhshayesh ow ra seresht be minu frestad janash khoday...

(Old Man) tells him: Oh! Unrivaled king! Guest of Old man, now is time to eat. Alexander answers him: eat! before (me) a part of this ripe fruit. Knowledgeable man: Oh! Unrivaled! Since 160 years ago (to now); Night and day I have kept my fast, (I eat) I have closed my mouth to speak. (I eat) only a day per year, when it is my Ceremony (cult). I nourish my body in this day, and this fruit is a kind of meal for my soul. $\mathrm{He}$ (Alexander) told him that: What is this respected day, the day when you are fortunate. He (Old man) answered that: third day, Ordībehešt, the day which is created by the generosity of the Lord. Adam went to the other world in this day, God sent his soul to Heaven...

This part of the Kush-nameh can be compared with Alexander's visit to India in Shah-nameh and with other Islamic texts. It suggests that

\footnotetext{
${ }^{1}$ I think that we are true if mention: "I predicted your events since 300 years ago than "my events" (old man). Old man speaks about majesty of Alexander, not himself.
} 
this particular story in the Kush-nameh may have been "an original source" for both epic texts, the Shah-nameh and the Kush-nameh.

Alexander visits Brahman's City during the invasion of India in Shah-nameh:

1051. vaz an jayagah lashkar andar kashid 1053. Brahman cho agah shod az kar shah 1054. pirastandeh mard andar amad ze kuh 1071. Sekandar cho ruy Brahman be did 1072. divan o brehneh tan o pay o sar 1073. ze barg giya pushesh az tokhm khard 1075. hameh khordanishan bar miveh-dar

daman ta be shahr Brahman rasid ke avard zan ruy lashkar be rah shodand andar an agahi ham-goruh bar an guneh avaz ishan shanid tanan bi-bar o jan ze danesh be bar bar asudeh az razm o ruz nabard ze tokhm giya rosteh bar kuhsar

Alexander rapidly went from there with his troop, to reach to Brahman's city. When Brahman found out about what the king had done, and that he (Alexander) had arrived with his troops, he (Brahman) descended from the mountain, and sent a letter to him. When Alexander met Brahman, and saw them; they come rapidly to him without wearing, anything (without covering the body and head), a knowledgeable people, but without covers. Their covers made of plants and their nourishment consisted of grain, Alexander didn't think to combat; because all their food was fruits, and grains which are found in mountains.

Now let us focus on the community in the Kush-nameh called the "Mountain People" and their beliefs as seen by Alexander. What kind of cult did they have? This community eats only "fish", "seeds" and "fruit". Geographically they live in or near China. Eating all "three" items is fine for some Iranians cults and tribes, while some items are prohibited by other cults. Perhaps Sogdian texts can help us here in clearing matters. Buddhism is the only religion which insists that its followers eat seeds (grains) and fruit. The followers do not eat "meat" or "fish" and "fishing" is prohibited in Buddhism. "The old wise man also emphasized eat only "fruit"'"

The relationship of Iranian Buddhists and Chinese Buddhists dates probably back to the Parthian period; Sogdian Buddhist texts 
are one of the most important Iranian Mid. Persian texts. This historical-religious relationship evidently continued to the end of Sasanian Period. The eating of "Fish" causes a problem in attributing this part of the text to Buddhism; but the eating of seeds and fruits are encouraged in Buddhist religion. Furthermore the lack of "wine" suggests Buddhist traces in this passage. In Or. 8212 (191), No. 11:

"Wine makes eyes darkness, tongue too stodgy, ears too deaf, make hands disable, foots to recumbent and immediately send to death. This liquor is criticism and drinking of it prohibited. It is better for people if they drink molten zinc than wine..."

28: The one who wants to follow Buddhism, thus should not drink wine" (Zarshenas: 2001, 25-29).

Manicheans also are well-known travelers in China and there are many similarities between Buddhist and Manichean texts. Manichean, who were masters in translating, translated different Buddhist texts. I think that eating fish can be part of Manichean beliefs in connection with Alexander's visit in the above tale. The two elements of Buddhism (seed/grain and fruit) are mingled with an element (fish) of Manichaeism. This factor (fish) cannot be related to Islamic beliefs, as it is not difficult to find such examples in Sogdian texts.

In regard to Manicheans Henning $(1945,465)$ writes:

"The role which the Manicheans played in the migration of tales and fables from East to West and West to East has received much attention in recent years. The Christian and Buddhist Sogdian texts are valuable merely as repositories of vocables, the Manichaean texts alone give us a clear idea of the true structure and syntax of the Sogdian language, and this quality is nowhere better apparent than in these stories, which are sometimes pleasingly vivid. Even the translated texts are written in good Sogdian, partly because the Manicheans were better translators than their Christian and Buddhist compatriots, partly because it was easier to translate from Middle Persian or Parthian, languages closely related to Sogdian, than from Syriac or Chinese". 
Henning (Ibd. 483) has shown that the "Kara Fish" tale is most probably a Buddhist tale which was translated by a Manichean translator, where here we find out about two elements in two cults. The appearance of two elements (fish and seeds) in this passage also recalls the famous tale of "Fisher and Farmer" in Sogdian texts. It seems that the Buddhist tale of "Fisher and Farmer" was one of the most popular tales amongst the Sogdians. The knowledgeable old man/wise man can also be a pious Manichean or a monk who lives in a cave and eats only fruit. He mentions: "I escaped from society and preferred this mountain"

696. to andar jahan name joee o kam 697. man izad-parastam, to giti-parast 698. bedan dur gashtam man az har goruh gorizan man az har do, az kam o nam negah kon konun ta ke bordeh ast dast gozidam ze giti yeki tigh kuh...

You wish title and desires in this world, but I hate both: desire and title. I am a worshiper of the Lord, you are a materialist, see carefully how will be the winner (me or you). For this reason I escaped from society, and selected the top of the mountain in this world.

His "ascetic life" can explain a characteristically Manichean monastic life. He has taken daily "fasts" and has eaten every night since 160 years ago. There are references to fasting not only in Manichean texts, but also in Buddhist texts. It is very clear that Zoroastrianism prohibited fasting for its followers and advised them to eat, to drink enough and enjoy their lives:

The Middle Persian text, Ardā Wìrāz (2003, no. 89) states:

“...These are souls of sinfuls who did not take food and garments to themselves..."(Cf. no. 31,77); The Sermon of Adurbād ì Mahraspandān states: "Take pastime and joyance in measure" (Navabi:1976, 562; Cf. Menog Xrad: 2000, no. 15). Wine also is free in Zoroastrianism. Now let us look at a tale of Shah-nameh:

It is very clear that Brahman in this Persian text means he who is a "knowledgeable man". Dehkhoda (1969, 1000; Borhan Qateh: 
1938, 202) describes it as a "noble and knowledgeable old man (priest) of Indians". W. Ball $(1976,125)$ writes: “Attention at Zir-rah (= a village at Bushehr province) is also drawn to the coincidence in the occurrence of the name 'Barmak', a village associated with the site of Tawwaj." According to local tradition this is an ancient name deriving from the Baramiki. R.W. Bulliet has drawn attention to this family as descendants of a Buddhist priestly caste from Bactria, the name Barmak deriving from the Sanskrit word baramika meaning "Buddhist priest".

Then Brahman can mean "knowledgeable man, knowledgeable old man"; I regard this word as "knowledgeable", as seen in the verse below by Hafez (Dehkhoda: Ibd.):

Mezaj dahr tebah shod dar in bela Hafez kojast fekr hakimi o ray Barahmani

It is clear that "Barahmani" means here "logic decision", which is confirmed by the word Hakimi, "sage".

Mahan/e/sh of Kush-nameh and Brahman of Shah-nameh both refer to a "religious knowledgeable (old) man" or generally a "knowledgeable man". This idea can support most probably by the terminology of Mahan/e/sh (> mah "great" and second part as an abbreviation for Dōniš(?) which can mean "knowledge and life"; the two terms as a compound name can mean "sage". Perhaps it can be said that the monks, masters translators and great leaders of Manicheans-Buddhists generally appear as "knowledgeable people" in the late texts, i.e. Islamic texts.

We also find Alexander's visit in other Islamic texts. Tha'libì (1989, 262) mentions this tale under: "the departure of Alexander to the Brahmanan's land" where the priests of this community appear as "knowledgeable people" and they only eat "fruit and vegetables" for food in their simple life.

"The community of Shah-nameh also lives in a mountain leading a kind of hermitic life, eating grains and fruits, and not interested 
in position and materials". Their "monk" is a knowledgeable old man. This passage is very similar to the Kush-nameh tale. Buddhist features are comprehensive in this tale where we can't find "fish" as a kind of nourishment. This factor marks a notable difference between the Shah-nameh and the Kush-nameh.

The rest of the Kush-nameh tale is also notable: a knowledgeable old man shows Alexander a parchment where his background for 300 years has been written. In Wìdēwdād (Chapter II), the Lord informed Jam (Jamshid), the mythological hero, "300" years of the future. The similarity of this number ( 300 "year"= time) is notable, especially in northern texts.

Alexander and his companions ask the old man different questions and he answers them (in both texts). He eats only "One day" per year" in the Kush-nameh. This day is "the third day of month, Ordibehešt; this name is one of the most familiar "Seven Holy Creatures" in Zoroastrianism. The "piety" and beauty (of the body) of the old man recall some of the characters of Ordibehešt, who is the symbol of Asha, "truth"; his duty is the observation of trees and pastures. I hope that I am right to take "Adam", a human prototype of Islam, as an element that replaced a Zoroastrianism factor in Islamic periods. Here, it is the "first" Iranian human prototype. Ordibehešt played an important role in the date of birthday of prophet, Zoroaster according to Den-kard.

The Dēnkard writes that: "Bahman with cooperation of Ordibehešt helped Zoroaster's parents to create him, to appear with a human shape and come from a "spiritual world" to a material world" (Tafazzoli: 1991, 40-41, 63). Adam went to the "spiritual world" on the day of Ordibehešt in the $\mathrm{KN}$; it is obvious that Ordibehešt played a role when Zoroaster came down from the spiritual world!

In fact Alexander's tales was one of the most familiar and famous tales for the different Iranian communities from pre-Islamic to Islamic time. Because of this, we are able to find different religious 
factors such as Buddhism, Manichaeism, Zoroastrianism and Islam in the tale of Alexander's visit to Central Asia and India. In brief, Alexander's visit is a collection of symbols which belong to different Iranian and non-Iranian religions.

\section{Conclusión:}

It seems that Alexander's tales affected Persian literature from Middle Persian to the Islamic texts from north to south. This characteristic of Persian literature, which goes back to fall of the Achaemenid, Parthian and Sasanian late antiquity periods, most probably influenced Islamic texts. It is very clear that "oral tradition" played important role in the Partho-Sasanian to Islamic periods. It is also clear that in Zoroastrian texts Alexander's invasion of Iran is described as a calamity. This calamity was recorded by Zoroastrian priests and only with regard to religious texts in a "religious tradition". In fact, it is most probable that the Khoday-nameh and definitely the "Oral tradition" of the Sasanian period followed a positive view of Alexander as part of a non-religious literature. It is possible that in these literary non-religious sources Alexander was a positive king, like an Iranian king. This is confirmed by the Shah-nameh, the Kush-nameh and many Islamic texts; the Iranians changed completely his personality.

One of Alexander's tales deals with the invasion of Central Asia and India in Persian Literature. It seems that this attack was kept alive by different Iranian tribes (oral) or perhaps by non-religious written sources. Many Iranian beliefs mingled with this tale because of the different geographical locations of Persian literature. The geographical location is one of the most important factors which makes a difference between Persian literature from north to south, Middle Persian to Islamic Periods (Ravaghi: 2004, introduction) - Middle Persian literature is more different from north to south because of Zoroastrianism in the south and Manicheans and Buddhists in the north, as well as historical relations with China and the regions around it. It is normal to have different beliefs amongst southern and northern writers, which influenced Persian literature 
at a time when Islamic writers collected and finalized their tales. The Silk Road was a major route for different Iranian tribes where they met foreigners. Furthermore Islamic writers replaced many Islamic symbols to Pre-Islamic symbols.

In fact a text like the Kush-nameh explains the elements of different Iranian beliefs from north to south, from Middle Persian to Islamic Periods in Alexander's tale. It seems that Alexander's tales were preserved generation after generation in Iran. The poet explains in his introduction that he wants to narrate a tale related to the "kingdom of China". This information is not only supported by intercultural relations between Iranian border regions and China, but also by the geographical district where poet is a native of it.

In short, the Silk Road was a gateway where many historicalreligious symbols of the three great cultures of the Iranian, Chinese and Roman empires were gathered. It is therefore not strange that these symbols appear in a text, like the KN. Alexander's visit was a popular tale amongst Iranians, and followers of different religions have incorporated their beliefs in this famous tale.

I believe that the Alexander tale is a unique collection about beliefs of different cults. The eating of Fish, living in a cave, ascetic living... recall Manichean features, and eating Fruit and Grain refers to Buddhism; Ordībehešt is the symbol of Zoroastrianism, while Adam as an Islamic symbol has replaced most probably a Zoroastrian belief. 


\section{Bibliography}

AKBARZADEH, D: 2007, Japan in Medieval Persian Manuscripts And Japan-Iran Relation, ICANAS 38, Ankara.

AKBARZADEH, D: 2010, Silla, Paradise of Ancient Iranians, HUFS, Korea Republic.

AKBARZADEH, D: 2013, A Term for Rome and Byzantium in the Persian Texts, Byzantion Nea Hellas, N 32, PP. 2013, 225 - 232, Chile.

BALL, W: 1976, “Two Aspects of Iranian Buddhism”, Bulletin of the Institute of Pahlavi University, No. 1-4, Shiraz.

BORHAN-E QATEH: 1938, M. Khalaf Tabrizi, I-IV., Tehran.

DARYAEE, T: 2009, Sasanian Persia (The rise and fall of an empire), London- New York.

DARYAEE, T: 2010,"Bazaar, Merchants, and Trade in Late Antique Iran", Comparative Studies of South Asia, Africa and the Middle East, Vol. 30, No. 3., London.

DEHKHODA, A: 1969, Loghat-nameh, Tehran

GHARIB, B: 2004, Sogdian Dictionary (Sogdian-Persian-English), $2^{\text {nd }}$. edit,Tehran.

HENNING, W. B: 1945, "Sogdian Tales", Bulletin of the School of Oriental and African Studies, University of London, Vol. 11, No. 3., pp. 465-487, London.

KUSH-NAMEH: 1998, Iranshan-ibn- Abal Khayr, corrector: J. Matini, Tehran.

LE LIVRE D' ARDĀ VĪRĀZ, Ph. Gignoux (Translitteration, transcription et traduction du texte Pehlevi): 2003, Traduction en Persan: Zh. Amouzegar, Tehran.

MAHYAR NAVABI, Y: 1976, Majmueh Maghalat (Complex of Articles), By. M. Tavousi, Shiraz. 
MINUY-E KHARAD: 2000, Translator: A. Tafazzoli, By. Zh. Amuzegar, $3^{\text {rd }}$ edition, Tehran.

RAVAGHI, A. (with Sh. Sayad): 2004, Zeban Farsi Frarudi (Tajdiki), Tehran.

SHAH-NAMEH YE FIRDOWSI: 1963-1970, Vol. I-IX, Moscow.

TAFAZZOLI, A and Zh. Amuzegar: 1991, Ostureh Zendegi Zardosht (Myth of Zoroaster), Tehran.

TAFAZZOLI, A: 1997, Tarikh Adebiyat Iran-e Pish az Islam, by Zh. Amuzgar, Tehran.

TARIKH THA'LABI: 1989, Abdolmalek ibn M. ibn. Esmail Tha'labi Nishaburi, By M. Fezaeli, Tehran.

VAISSIERE, E: 2005, Sogdian Traders (A History), Translated by J. Ward, Leiden.

ZARSHENAS, Z: 2001, Six Sogdian Texts (Part I), Tehran. 